\title{
PENGARUH PEMBERIAN LEAFLET \\ TERHADAP DISIPLIN PENGGUNAAN HELM PADA MAHASISWA IKM PEMINATAN K3 DAN NON PEMINATAN K3 STIKES HANG TUAH PEKANBARU
}

\author{
Kiki Fitriza Milda ${ }^{1}$, Santoso ${ }^{2}$, Endang Purnawati Rahayu ${ }^{3}$, Asril $^{4}$, Kamali Zaman ${ }^{5}$ \\ 1,2,3,4,5 Program Studi Magister Ilmu Kesehatan Masyarakat, STIKes Hang Tuah Pekanbaru \\ Email: Realityqqfm@yahoo.co.id
}

\section{Diterima: Oktober 2020, Diterbitkan: Desember 2020}

\begin{abstract}
ABSTRAK
Kedisiplinan dalam berlalu lintas merupakan bentuk perilaku tanggung jawab seseorang terhadap peraturan yang berlaku di jalan raya misalnya kedisiplinan menggunakan helm. Hasil observasi mahasiswa IKM khususnya peminatan K3 dan Promkes ketika mengendarai kendaraan ke kampus tidak menggunakan helm. Penelitian ini bertujuan untuk menganalisis pengaruh pemberian leaflet terhadap disiplin penggunaan helm. Jenis penelitian yang digunakan bersifat kuantitatif eksperimental dengan desain Quasi Eksperiment Non Control. Sampel dalam penelitian ini berjumlah 40 responden. Analisis data yang digunakan adalah univariat dan bivariat. Hasil penelitian ini menyimpulkan bahwa pada kelompok IKM peminatan $\mathrm{K} 3$ ada pengaruh pemberian leaflet terhadap pengetahuan penggunaan helm dengan nilai $\mathrm{p}$ value $<$ alpha $(0,035<0,05)$ dan tidak adanya pengaruh pemberian leaflet terhadap sikap penggunaan helm dengan nilai $p$ value $>$ alpha $(0,143>0,05)$ sedangkan pada kelompok non peminatan $\mathrm{K} 3$ tidak ada pengaruh pemberian leaflet terhadap sikap penggunaan helm dengan nilai $\mathrm{p}$ value $>$ alpha $(0,377>0,05)$ dan ada pengaruh pemberian leaflet terhadap pengetahuan penggunaan helm dengan nilai $\mathrm{p}$ value $<$ alhpa $(0,039<0,05)$. Disarankan kepada institusi pendidikan untuk membuat kebijakan dan peraturan penerapan menggunakan helm, melakukan sosialisasi PKKMB berkewajiban menggunakan helm kepada mahasiswa baru dengan melibatkan kepolisian.
\end{abstract}

Kata Kunci : Pengetahuan, Sikap, Disiplin Menggunakan Helm

\section{ABSTRACT}

Discipline in traffic is a form of responsible behavior towards the regulations that apply on a highway, for example discipline in using a helmet. The results of observations of IKM students, especially in $K 3$ and Promkes specialization when vehicles to campus do not use helmets. This study aims to analyze the effect of leaflet distribution on helmet use. This type of research is quantitative experimental with a Quasi Experiment Non Control design. The sample in this study was 40 respondents. The data analysis used was univariate and bivariate. The results of the study concluded that the K3 specialization IKM group had the effect of presenting leaflets on knowledge of helmet use with a value of $p<$ alpha $(0.035<0.05)$ and there was no effect of leaflet giving on helmet use attitudes with $p$ value $>$ alpha $(0.143>0,05)$ whereas in the nonK3 specialization group there was no effect of presenting leaflets on the attitude of using helmets with a $p$ value $>$ alpha (0.377> 0.05) and there was an effect of presenting leaflets on knowledge of helmet use with a p value <alpha $(0.039<0$, 05). It is recommended that institution to make policies and implement policies of using helmet, to conduct socialization of obligatory using helmet in PKKMB.

Keywords $\quad$ : Knowledge, Attitude, Discipline Using Helmet. 


\section{PENDAHULUAN}

Penggunaan

perlengkapan

keselamatan adalah salah satu syarat dalam mengoperasikan kendaraan bermotor baik roda dua ataupun roda 4 . Dalam Undang-Undang no 22 tahun 2009 tentang lalu lintas dan angkutan jalan bahwa setiap pengemudi yang tidak menggunakan helm akan diberi saksi yaitu pidana kurungan 1 bulan atau denda maksimal Rp.250.000. Pemakaian alat keselamatan ini, terutama helm pada pengguna kendaraan roda dua, seringkali diabaikan terutama oleh penumpangnya. Alasan yang digunakan ketika mengabaikan penggunaan helm antara lain jarak bepergian yang dekat, tidak nyaman menggunakan helm, dan tidak memiliki helm.

World Health Organization (WHO) mencatat hampir 3400 orang di dunia meninggal setiap harinya akibat kecelakaan lalu lintas dan puluhan juta orang terluka setiap tahunnya. Secara umum Kepolisian Republik Indonesia (POLRI) yang dikutip dari Badan Pusat Statistik (BPS), pada tahun 2015 jumlah kecelakaan lalu lintas tercatat ada 98.970 kecelakaan, dengan rincian korban meninggal sebanyak 26.495, orang luka berat 23.937, orang luka ringan sebanyak 110.448 orang dan kerugian material sebanyak 272 milyar rupiah. Pertumbuhan kendaraan bermotor didunia pun mencapai 113.030.793 unit.

Berdasarkan data yang didapat dari Polresta Kota Pekanbaru tercatat kecelakaan lalu lintas pada sepeda motor tahun 2016 yaitu 212 kecelakaan lalu lintas. Dengan korban meninggal dunia 91 orang, 40 orang luka berat, 178 luka ringan dengan total kerugian material sebesar $\mathrm{Rp}$ 657.850.000. Sedangkan pada tahun 2017 sebanyak 191 kecelakaan lalu lintas, 102 korban meninggal dunia, 78 luka berat dan 158 luka ringan dengan total kerugian material Rp 721.400.000 dan pada tahun 2018 sebanyak 196 korban kecelakaan lalu lintas, 83 korban meninggal dunia, 72 luka berat dan 292 luka ringan dengan total kerugian material Rp 566.000.000. Data berdasarkan jumlah usia pelaku laka lantas pada usia remaja 18 sampai 25 tahun meningkat pada tahun 2018 dengan jumlah laka 60 orang. Sedangkan data tilang yang penulis dapat berdasarkan pelanggaran penggunaan helm pada tahun 2016 yaitu 4132 pelanggaran penggunaan helm, tahun 2017 yaitu 5634 pelanggaran penggunaan helm, tahun 2018 yaitu 5660 . (Data Polresta Pekanbaru).

Berdasarkan

penelitian

Perwitaningsih (2013), berdasarkan analisis data melalui metode pemberian leaflet dapat diketahui bahwa terdapat pengaruh yang signifikan faktor pengetahuan, sikap terhadap peraktik keselamatan dan kesehatan berkendara sepeda motor pada mahasiswa.

STIKes Hang Tuah memiliki peminatan K3 yang mengerti tentang safety, maka penulis ingin mengetahui sejuah mana pengetahuan dan sikap mereka dalam disiplin penggunaaan helm baik itu IKM peminatan K3 dan non peminatan K3. Dan didukung data dari Polresta Pekanbaru pada tahun 2018 meningkat dengan jumlah kecelakaan lalu lintas 196 korban, pada usia remaja umur 18 sampai 25 tahun dengan jumlah laka 60 orang dan diperkuat dengan data tilang pelanggaran penggunaan helm, tahun 2018 meningkat yaitu 5660 kasus. Berdasarkan data yang tercatat, terus terjadi peningkatan disetiap tahunnya. Maka dengan ini sangat perlu dilakukan peningkatan kesadaran bagi mahasiswa STIKes Hang Tuah Pekanbaru tentang pentingnya keselamatan dalam berkendara dan pemakaian alat keselamatan yaitu helm bagi pengguna motor.

Dari latar belakang diatas dapat ditarik permasalahan untuk dijadikan perumusan masalah dalam penelitian ini yaitu "Apakah ada pengaruh pemberian leaflet terhadap disiplin penggunaan helm pada mahasiswa IKM peminatan K3 dan non peminatan K3 STIKes Hang Tuah Pekanbaru tahun 2019" 


\section{METODE PENELITIAN}

Penelitian ini merupakan penelitian Quasi Eksperiment Non Control yang bersifat kuantitatif. Penelitian ini dilakukan dengan pengamatan antara variable dependen (pemberian leaflet) dan variabel independen (pengetahuan, sikap dan kedisiplinan menggunakan helm). Populasi dalam penelitian ini yaitu mahasiswa IKM peminatan K3 dan non peminatan K3 STIKes Hang Tuah Pekanbaru. Prosedur pengambilan sampel menggunakan teknik Non Probability sampling dengan purpossive sampling sesuai dengan kriteria yaitu Mahasiswa STIKes Hang Tuah yang menggunakan sepeda motor ke kampus, Mahasiswa STIKes Hang Tuah yang aktif dan bersedia diwawancarai. Besar sampel yang akan diambil adalah 40 mahasiswa, masing-masing 20 mahasiswa peminatan K3 dan 20 non peminatan K3.

Pengukuran awal pretest dilakukan tanggal 26 Juni 2019 dengan memberikan kuesioner pada 2 peminatan yaitu IKM peminatan $\mathrm{K} 3$ dan non peminatan K3 masing-masing peminatan berjumlah 20 orang. Setelah itu diberi intervensi berupa leaflet mengenai disiplin penggunaan helm yang berisi tentang keselamatan berkendara, peraturan mengenai kewajiban menggunakan helm dan teknik menggunakan helm dengan baik. Seminggu kemudian yaitu pada tanggal 04 Juni 2019 dilakukan pengukuran untuk kedua kalinya (posttest) kepada kedua peminatan tersebut

Pengolahan data dalam penelitian ini yaitu coding merupakan memberikan kode tahap tiap kategorik, Editing merupakan memeriksa kelengkapan jawaban kuesioner yang di isi oleh responden, Entry merupakan kegiatan memasukkan data yang telah dikumpulkan ke dalam master table, Cleaning merupakan kegiatan pengecekan kembali data yang sudah di entry, Tabulating merupakan tahapan kegiatan pengorganisasisan data. Kemudian data di analisis dengan analisis univariat dan analisis bivariate dengan menggunakan uji T berpasangan (paired $t$ test).

\section{HASIL PENELITIAN Analisis Univariat}

Rata-rata nilai pretest Variabel Dependen (disiplin penggunaan helm) pada kelompok IKM PEMINATAN K3 mengalami kenaikan setelah diberikan leaflet selama 1 (Satu) minggu yaitu sebesar mean 6,85 \pm SD 1,348. Sementara rata-rata nilai pretest variabel Independen (pengetahuan dan sikap) pada kelompok IKM peminatan K3 mengalami kenaikan setelah diberikan leaflet selama 1 (Satu)minggu yaitu pengetahuan mean $7,65 \pm \mathrm{SD} 1,461$; sikap mean 7,40 $\pm \mathrm{SD}$ 0,681 .

Rata-rata nilai pretest variabel dependen (disiplin penggunaan helm) pada kelompok IKM non pemintan K3 mengalami penurunan setelah diberikan leaflet selama 1 (satu) minggu yaitu sebesar mean 5,65 \pm SD 1,814. Sementara rata-rata nilai pretest variabel independen (pengetahuan dan sikap) pada kelompok IKM non pemintan K3 mengalami kenaikan setelah diberikan leaflet selama 1 (satu) minggu yaitu pengetahuan mean $7,45 \pm \mathrm{SD} 1,468$ dan sikap mean6,10 $\pm \mathrm{SD}$ 1,021 .

\section{Normalitas Data}

Hasil uji normalitas data yang digunakan yaitu uji Shapiro-Wilk, ratarata $p$ value lebih kecil daripada nilai alpha $(p \leq 0,05)$. Uji yang digunakan adalah uji non parametrik. 


\section{Analisis Bivariat}

Tabel 1. Hasil Uji Non Parametrik

\begin{tabular}{|c|c|c|c|c|c|}
\hline Uji Wilcoxon & Neg & Pos & Ties & n & $P$ \\
\hline $\begin{array}{l}\text { IKM Peminatan K3 } \\
\text { Peng_PostTest- } \\
\text { Peng_PreTest }\end{array}$ & 2 & 13 & 5 & 20 & 0,002 \\
\hline $\begin{array}{l}\text { IKM non K3 } \\
\text { Peng_PostTest- } \\
\text { Peng_PreTest }\end{array}$ & 1 & 13 & 6 & 20 & 0,005 \\
\hline $\begin{array}{l}\text { IKM Peminatan K3 } \\
\text { Sikap_PostTest- } \\
\text { Sikap_PreTest }\end{array}$ & 1 & 12 & 7 & 20 & 0,003 \\
\hline $\begin{array}{l}\text { IKM non K3 } \\
\text { Sikap_PostTest- } \\
\text { Sikap_PreTest }\end{array}$ & 8 & 8 & 4 & 20 & 0,384 \\
\hline $\begin{array}{l}\text { IKM Peminatan K3 } \\
\text { Disip_PostTest- } \\
\text { Disip_PreTest }\end{array}$ & 4 & 14 & 2 & 20 & 0,010 \\
\hline $\begin{array}{l}\text { IKM non K3 } \\
\text { Disip_PostTest- } \\
\text { Disip_PreTest }\end{array}$ & 10 & 8 & 2 & 20 & 0,207 \\
\hline
\end{tabular}

Didapatkan bahwa pada kelompok IKM peminatan $\mathrm{K} 3$ untuk pengetahuan pretest dengan postest diperoleh nilai $p$ value $=0,002$ lebih kecil daripada nilai alpha $(p \leq 0,05)$ sehingga Ho ditolak maka dapat disimpulkan bahwa ada perbedaan pengetahuan sebelum diberikan leaflet dan setelah diberikan leaflet. Sementara pada kelompok IKM non pemintan K3 untuk pengetahuan pretest dengan posttest diperoleh nilai $p$ value $=0,005$ lebih kecil daripada nilai alpha $(p \leq 0,05)$ sehingga Ho ditolak maka dapat disimpulkan bahwa ada perbedaan pengetahuan sebelum diberikan intervensi dan setelah diberikan leaflet

\section{Uji Non Parametrik (Wilcoxon) Sikap}

Didapatkan bahwa pada kelompok IKM peminatan K3 untuk sikap pretest dengan postest diperoleh nilai $p$ value $=$ 0,003 lebih kecil daripada nilai alpha ( $p \leq$ $0,05)$ sehingga Ho ditolak maka dapat disimpulkan bahwa ada perbedaan sikap sebelum diberikan leaflet dan setelah diberikan leaflet. Sementara pada kelompok IKM non peminatan K3 untuk sikap pretest dengan postest diperoleh nilai $p$ value $=0,384$ lebih besar daripada nilai alpha $(p \geq 0,05)$ sehingga Ho diterima maka dapat disimpulkan bahwa tidak ada perbedaan sikap sebelum diberikan leaflet dan setelah diberikan leaflet.

\section{Uji Non Parametrik (Wilcoxon) Disiplin}

Didapatkan bahwa pada kelompok IKM peminatan K3 untuk disiplin pretest dengan postest diperoleh nilai $p$ value $=$ 0,010 lebih kecil daripada nilai alpha ( $p \leq$ $0,05)$ sehingga Ho ditolak maka dapat disimpulkan bahwa ada perbedaan disiplin sebelum diberikan leaflet dan setelah diberikan leaflet. Sementara pada kelompok IKM non peminatan K3 untuk disiplin pretest dengan postest diperoleh nilai $p$ value $=0,207$ lebih besar daripada nilai alpha $(p \geq 0,05)$ sehingga Ho ditterima maka dapat disimpulkan bahwa tidak ada perbedaan disiplin sebelum diberikan leaflet dan setelah diberikan leaflet.

Tabel 2. Uji Man whitney Pengetahuan dan Sikap pada mahasiswa IKM peminatan K3.

\begin{tabular}{lcccc}
\hline \multicolumn{1}{c}{$\begin{array}{c}\text { Uji Man } \\
\text { whitney }\end{array}$} & $\begin{array}{c}\text { Tingkat } \\
\text { Disiplin }\end{array}$ & $\begin{array}{c}\text { Mean } \\
\text { Rank }\end{array}$ & n & $\begin{array}{c}\boldsymbol{P} \\
\text { value }\end{array}$ \\
\hline IKM & Tidak & 6,33 & 20 & 0,035 \\
K3 & Disiplin & 12,29 & & \\
Pengetahuan & & & & \\
\hline Sikap & Tidak & 7,83 & 20 & 0,143 \\
& Disiplin & 11,64 & & \\
\hline IKM & Tidak & 7,56 & 20 & 0,039 \\
non K3 & Disiplin & 12,91 & & \\
Pengetahuan & & & & \\
\hline \multirow{2}{*}{ Sikap } & Tidak & 9,28 & 20 & 0,377 \\
& Disiplin & 11,50 & & \\
\hline
\end{tabular}

Didapatkan bahwa setelah diberikan leaflet kepada mahasiswa IKM peminatan $\mathrm{K} 3$ diperoleh nilai $p$ value $=$ 0,035 nilai tersebut lebih kecil daripada nilai alpha $(p \leq 0,05)$ artinya pengetahuan memiliki pengaruh terhadap disiplin penggunaan helm. Sikap diperoleh nilai $p$ value $=0,143$ lebih besar daripada nilai alpha $(p \geq 0,05)$ artinya sikap tidak memiliki pengaruh terhadap disiplin penggunaan helm

Uji Man whitney Pengetahuan dan Sikap pada mahasiswa IKM non pemintan K3 
penggunaan helm. Sikap diperoleh nilai $p$ value $=0,377$ lebih besar daripada nilai alpha $(p \geq 0,05)$ artinya Didapatkan bahwa setelah diberikan leaflet kepada mahasiswa IKM non pemintan K3 diperoleh nilai $p$ value $=0,039$, nilai tersebut lebih kecil daripada nilai alpha ( $p$ $\leq 0,05)$ artinya pengetahuan memiliki pengaruh terhadap disiplin sikap tidak memiliki pengaruh terhadap disiplin penggunaan helm.

\section{Pembahasan}

\section{Perbedaan pengaruh pengetahuan dalam pemberian leaflet terhadap disiplin penggunaan helm pada mahasiswa IKM Peminatan K3 dan non Peminatan K3.}

Pemberian leaflet memiliki pengaruh yang positif terhadap peningkatan pengetahuan mahasiswa. Dari hasil penelitian pengetahuan mahasiwa IKM peminatan $\mathrm{K} 3$ dan non pemintan $\mathrm{K} 3$ terkait pemberian leaflet masih terlihat rendah dari sisi peraturan yang mengatur tentang aturan berkendara, dari 40 orang mahasiswa yang diteliti terdapat 18 orang (45\%) menjawab salah, namun setelah diberikan intervensi dengan menggunakan leaflet tingkat pengetahuan mahasiswa terhadap autran berkendara meningkat menjadi 31 orang $(77,5 \%)$.

Menurut teori Lawrence Green yang menyatakan bahwa pengetahuan merupakan salah satu faktor yang mempermudah atau mempredisposisi terjadinya prilaku seseorang begitu juga sebaliknya prilaku seseorang dipengaruhi oleh pengetahuannya sendiri yang merupakan faktor internal dari dalam diri sendiri. Juga sependapat dengan teori dari Snehandu B.Karr yang mengatakan bahwa determinan prilaku seseorang dipengaruhi oleh terjangkaunya informasi atau bisa dikatakan pengetahuan terkait dengan tindakan yang akan diambil oleh seseorang. (Notoatmodjo, 2013).

Menurut Maulana (2009) untuk membina dan meningkatkan kesadaran masyarakat, intervensi atau upaya yang dilakukan yang ditujukan kepada perubahan faktor prilaku sangat penting mengingat pengaruh yang ditimbulkannya. Kegiatan pendidikan kesehatan erat kaitannya terhadap peningkatan pengetahuan masyarakat. Pemberian leaflet pada penelitian ini merupakan suatu bentuk upaya dalam meningkatkan pengetahuan mahasiswa terkait kedisiplinan penggunaan helm. Hasil penelitian ini sejalan dengan penelitian yang dilakukan oleh Sambodo (2010) yang menyebutkan bahwa terdapat hubungan yang bermakna antara pengetahuan dengan prilaku penggunaan helm SNI (Helm Standar Nasional Indonesia) pada Mahasiswa FKM (Fakultas Kesehatan Masyarakat) Universitas Diponogoro Semarangan dengan nilai $P$ value $=0,007$.

\section{Perbedaan pengaruh sikap dalam pemberian leaflet terhadap disiplin penggunaan helm pada mahasiswa IKM Peminatan K3 dan non Peminatan K3}

Pemberian leaflet tidak memiliki pengaruh terhadap disiplin menggunakan helm. Pada pernyataan sikap sebanyak 9 responden $(22,5 \%)$ memilih tidak menggunakan helm karena tidak terkena sanksi sementara setelah diberikan intervensi menggunakan leaflet tidak terjadi perubahan sikap yaitu sebanyak 9 responden $(22,5 \%)$ tidak menggunakan helm karena tidak terkena sanksi. Sehingga dapat disimpulkan bahwa responden tetap ingin menciptakan rasa aman saat berkendara apabila ada polisi yang mengawasi atau perjalanan jarak jauh saja. Menurut peneliti sikap masih merupakan suatu rekasi tertutup dan bukan merupakan suatu prilaku sebab seseorang sering memperlihatkan prilaku yang tidak mencerminkan sikapnya.

Menurut Maulana (2009) sikap tidak sama dengan prilaku dan prilaku tidak selalu mencerminkan sikap seseorang, 
individu sering sekali memperlihatkan tindakan yang bertentangan dengan sikapnya. Pada penelitian ini pada kelompok IKM peminatan K3 walaupun mahasiswa tersebut memiliki minat dalam pembelajaran K3 namun sikap mahasiswa tersebut belum tentu mencerminkan terhadap prilaku dalam disiplin menggunakan helm.

Hal ini menunujukan kurang sesuainya teori yang menyebutkan bahwa sikap masih merupakan salah satu faktor yang mempermudah atau mempredisposisi terjadinya prilaku seseorang begitu juga sebaliknya prilaku seseorang dipengaruhi oleh predisposisi yaitu sikapnya sendiri. (Notoadmodjo, 2013). Sikap sebagai faktor determinan prilaku dalam teori snehandu B. Karr yaitu termasuk adanya niat (intention) seseorang untuk bertindak. Seperti dalam buku WHO (2014) menyebutkan bahwa masyarakat tidak terlalu peduli dan sikapnya tidak terlalu mendukung peraturan perundangundangan tentang keharusan memakai helm, penegakan hukum memerlukan dukungan pemerintah secara luas.

Penelitian ini didukung dengan penelitian yang dilakukan oleh Fadilah (2018) yang menyebutkan bahwa tidak terdapat hubungan antara sikap dengan prilaku menggunakan helm pengendara sepeda motor pada pelajar kelas $\mathrm{X}$ (sepuluh) dengan nilai $p$ value $=0,125$.

\section{Perbedaan pengaruh kenyamanan dalam pemberian leaflet terhadap disiplin penggunaan helm pada mahasiswa IKM K3 dan bukan IKM K3}

Pemberian leaflet tidak memiliki pengaruh yang positif terhadap kenyamanan disiplin menggunakan helm. Pada kelompok bukan IKM K3 didapatkan nilai $p$ value $=0,370$, nilai tersebut lebih besar dari pada nilai alpha $(\mathrm{p}<0,05)$ sehingga dapat disimpulkan bahwa kenyamanan dengan metode menggunakan leaflet tidak berpengaruh terhadap disiplin menggunakan. Hal ini dapat disimpulkan bahwa dalam hal kenyamanan kelompok IKM K3 memiliki pengaruh yang signifikat terhadap disiplin penggunaan helm dibandingkan dengan kelompok bukan IKM K3.

Perasaan tidak nyaman yang timbul pada saat menggunakan helm akan mengakibatkan keengganan pengendara sepeda motor menggunakannya dan mereka memberi respon yang berbedabeda. Respon tersebut yaitu menahan rasa tidak nyaman dan tetap memakai, sesekali melepas, hanya digunakan pada saat tertentu, tidak digunakan sama sekali, merasa nyaman tetap menggunakan alat pelindung diri (A. M. Sugeng Budiono, 2003:334).

Perbedaan rasa nyaman menggunakan helm pada mahasiswa IKM K3 dan bukan IKM K3 merupakan suatu perbedaan subjektif pada masing-masing individu. Pada saat peneliti melakukan wawancara pada beberapa mahasiswa mereka bukan sama sekali tidak menggunakan helm akan tetapi pernah tidak menggunakan helm karena alasan lupa dan terburu-buru. Menurut Gempur (2004) alasan pengendara sepeda motor tidak mau memakai alat pelindung diri adalah tidak sadar atau tidak mengerti, panas, sesak, tidak enak dipakai, tidak enak dipandang, berat, tidak sesuai dengan bahaya yang ada, tidak ada sangsi.

Perbedaan rasa nyaman pada mahasiswa IKM K3 didukung oleh faktor jenis helm yang saat ini sudah didukung ventilasi udara sehingga sejuk ketika digunakan dan jenis kaca helm yang dilengkapi anti terik matahari.

Hasil penelitian kusuma yuda reza (2013) tentang hubungan antara pengetahuan, sikap dan kenyamanan dengan menggunakan alat pelindung wajah. Hasil ini didasarkan pada uji alternatif Fisher, diperoleh p-value sebesar $0,002(\mathrm{p}<0,05)$

\section{Kesimpulan}

Pengaruh pemberian leaflet terhadap disiplin penggunaan helm pada mahasiswa IKM peminatan K3 dan non peminatan K3 
STIKes Hang Tuah Pekanbaru dapat disimpulkan bahwa: Adanya perbedaan pengetahuan sebelum dan sesudah diberikan leaflet. Adanya perbedaan sikap sebelum dan setelah diberikan leaflet. Adanya perbedaan disiplin sebelum dan setelah diberikan leaflet. Pemberian leaflet memiliki pengaruh yang positif terhadap pengetahuan disiplin menggunakan helm. Pemberian leaflet memiliki pengaruh yang positif terhadap sikap disiplin menggunakan helm. Pemberian leaflet tidak memiliki pengaruh yang positif terhadap kenyamanan disiplin menggunakan helm

\section{Saran}

Dari hasil penelitian ini penting bagi pihak kampus IKM STIKes Hang Tuah Pekanbaru agar dapat membuat kebijakan terkait kedisiplinan mahasiswanya dalam keharusan menggunakan helm saat berkendara, kampus STIKes Hang Tuah Pekanbaru juga didukung dengan peminatan yang sejalan dengan nilai-nilai keselamatan sudah seharusnya mendukung program keselamatan berkendara dimulai dengan mewajibkan mahasiswanya menggunakan helm saat berkendara terutama ke dalam lingkungan kampus. Selain itu dengan adanya kebijakan tersebut peran kampus mendukung program pemerintah dalam menegakkan Undang-Undang no 22 tahun 2009 tentang lalu lintas dan angkutan jalan, sehingga diharapkan mahasiswa IKM peminatan K3 menjadi pelopor keselamatan dalam berlalu lintas.

\section{Daftar Pustaka}

Anggarasena, B. (2010). Strategi Penegakkan Hukum dalam Rangka Meningkatkan Keselamatan Lalu Lintas dan Mewujudkan Masyarakat Patuh Hukum. Tesis pada Program Pasca sarjana Universitas Dipenogoro. Tidak Diterbitkan.

Anggraini. D. (2013). Studi tentang Perilaku Pengendara Kendaraan Bermotor DiKota Samarinda dalam
E-JournalSosiatri-Sosiologi, 1 (1), 10-19.

Aris, Pentingnya Menggunakan Helm Saat Berkendara Sepeda Motor, http://www.welovehonda.com/pentin gnya-menggunakan-helm-saat-

berkendara-sepeda-motor/ diakses tanggal 10 februari 2015.

Astuti, R.F. dan I Made S. (2015). Disiplin Di Jalan Raya Pada Remaja Di Desa Petak, Pacet, Mojokerto. EJurnal Kajian Moral dan Kewarganegaraan. Volume 02 Nomor 03 Tahun 2015, 831-845.

BSN. (2007). "Helm Pengendara Kendaraan Bermotor Roda Dua"

Damayanti, C. Dkk. (2013). Meningkatkan Perilaku Disiplin Berlalu Lintas dengan menggunakan layanan konseling kelompok. Jurnal Bimbingan dan konseling FKIP Universitas Lampung. Tahun 2013: hal $1-12$

Dirjen Perhubungan Darat. (2008). "Buku Petunjuk Tata Cara Bersepeda Motor di Indonesia".

Drs. CST. Kansil, S.H. Disiplin Berlalu Lintas di Jalan Raya Rineka Cipta, 1995

Fadilah, Deden (2018). Faktor-faktor yang berubungan dengan prilaku pemakaian helm pengendara sepeda motor pada pelajar kelas X (Sepuluh). Promotor. Jurnal Mahasiswa Kesehatan Masyarakat Vol 01. No. 01.2018

Hendi Ismail, Manfaat Mengunakan Helm Saat berkendara, https://www.cekpremi.com/blog/man faat-menggunakan-helm-saat-

berkendara/,diakses tanggal 10 februari 2019.

Kholifah, Siti. (2017). “ Hubungan Jarak Tempat Tinggal Dan Tingkat Pendidikan Terhadap Tingkat Kunjungan Masyarakat Ke Puskesmas". Bandar Lampung : Universitas Lampung

Kusmagi, Marye Agung. (2010). Selamat Berkendara di Jalan Raya. Depok : 
Raih Asa Sukses (Penebar Swadaya Grup)

Lapau,B., (2012). Metode Penelitian Kesehatan, Jakarta.

Maulana, Heri (2009). Promosi Kesehatan. Jakarta : Penerbit Buku Kedokteran

Motorcycle Safety Foundation. (2014). “ The Motorcycle Safety Foundation Basic Riderscourse Rider Handbook" Notoatmodjo, S. (2013). Promosi Kesehatan Teori dan Aplikasinya. Jakarta : Rineka Cipta

Notoatmodjo, S. (2010). Promosi Kesehatan Teori Perilaku dan Aplikasi. Jakarta : Rineka Cipta

Notoatmodjo, S. (2012). Promosi Kesehatan dan perilaku kesehatan. Jakarta : Rineka Cipta

Peraturan Pemerintah Republik Indonesia No.34 tahun 2006 tentang Jalan

Peraturan Pemerintah Republik Indonesia. (2012). “ Tata Cara Pemeriksaan Kendaraan Bermotor di Jalan dan Penindakan Pelanggaran Lalu Lintas dan Angkutan Jalan".

Perwitaningsih, Riyan. (2013). “ Hubungan Antara Pengetahuan Dan Sikap Terhadap Praktik Keselamatan Dan Kesehatan Berkendara Sepeda Motor Pada Mahasiswa Kesehatan Masyarakat". Semarang : Universitas Dian Nuswanto

POLRI. (2018). "Data Kecelakaan Lalu Lintas".Pekanbaru : Sat Lantas Polresta

POLRI. (2018). Sat Lantas Polresta Pekanbaru. 2018

Pratiwi, Sheliona. (2018). “ Pengaruh Pemberian Leaflet Terhadap Pengetahuan Safe Driving Dengan Metode Smith System Pada Pekerja". Pekanbaru : Sekolah Tinggi Ilmu Kesehatan Hang Tuah

Puspitasari, A. D. \& Hendrati, L. Y., (2013). Hubungan Antara Faktor Pengemudi dan Faktor Lingkungan Dengan Kepatuhan Mengendarai
Sepeda Motor. Jurnal Berkala Epidemiologi, I(2), pp. 192-200.

Ridho, M. (2012). “ Hubungan Persepsi Risiko Keselamatan Berkendara Dengan Perilaku Pemakaian Helm Pada Mahasiswa". Jakarta: Universitas Indonesia Depok

Sambodo, Priyo (2010). Faktor-Faktor Yang Berhubungan dengan Penggunaan Helem Standar Nasional (SNI) oleh Pengendara Sepeda Motor Sebagai Alat Pelindung Keselamatan Berkendara (studi pada mahasiswa FKM UNDIP Semarang)

Sugiyono. (2012). Metode Penelitian Kualitatif dan R\&D. Bandung: Alfabeta.

Setiawan, J. (2014). Latar Belakang Perilaku Remaja Dalam Mengemudikan Sepeda Motor Tanpa Surat Ijin Mengemudi (Studi Kasus Pelajar SMPN 11 Kota Samarinda). eJournal Ilmu Sosiatri, 1-14.

Suryaramadhanty, Rizqi. (2017). Gambaran Perilaku Pengendara Dalam Memakaikan Helm Pada Penumpang Anak Sekolah Dasar di SDN 03 Cipinang Melayu Jakarta Timur". Jakarta : Universitas Islam Negeri Syrif Hidayatullah

Tondok,MS. (2012). "Intensi Kepatuhan Menggunakan Helm Pada Pengendara Sepeda Motor : Aplikasi Teori Perilaku Terencana". Surabaya : Universitas Falkutas Psikologi

Undang-Undang No.38 tahun 2004 tentang Jalan

Utari, G., (2010). Hubungan Pengetahuan, Sikap, Persepsi dan Keterampilan Mengendarai Mahasiswa Terhadap Perilaku Keselamatan Berkendara, Jakarta: Fakultas Kedokteran dan Ilmu Kesehatan UIN Syarif Hidayatullah.

UULLAJ. (2009). Undang -Undang Republik Indonesia Nomor 22 Tahun 2009 Tentang Lalu Lintas dan Angkutan Jalan.

Wulandari, F. (2015). Pemahaman pelajar tentang disiplin berlalu lintas 
(studi di smk kesehatan samarinda). eJournal Sostria-Sosiologi, 1 (3), 53

Yogatama, Leo Agung Manggala. 2013."

Analisis

Pengaruh

Attitude,Subjective Norm, Perceived

Behavior Control Terhadap Intensi

Penggunaan Helm saat Mengendarai

Motor Pada Remaja dan Dewasa

Muda di Jakarta Selatan". Jakarta :

Universitas Atma Jaya 